\title{
Medikal Sektörde Faaliyet Gösteren Firmaların Performanslarının Ölçümü ve Nitel Firma Karakteristikleri ile Çoklu Uyum Analizi ${ }^{1}$
}

\author{
Selahattin Kaynak ${ }^{2}$ \\ Miraç Eren ${ }^{3}$
}

Medikal Sektörde Faaliyet Gösteren Firmaların Performanslarının Ölçümü ve Nitel Firma Karakteristikleri ile Çoklu Uyum Analizi

Öz

Dünyada inovatif faaliyetler ve patent başvuruları çoğunlukla medikal sektörde gerçekleşmektedir. Türkiye, son yıllarda medikal sektörde yüksek teknoloji içerikli ürünler üretebilme ve innovatif yaklaşımlarla küresel piyasalarda yer alabilme amacını taşımaktadır. Bu amaca ulaşmak için de sektörde faaliyet gösteren firmaların, küresel rekabet koşullarında varlık gösterebilmelerini sağlayacak olan kaynaklarını etkin bir şekilde kullanmaları ve etkinsizliğe neden olabilecek karakteristikleri saptayıp önlem almaları gerekmektedir. Bu araştırma kapsamında Samsun'da medikal sektörde faaliyet gösteren firmaların ihracat ve inovasyon performansları, veri zarflama metodolojisine dayanarak birbiri içerisinde göreceli olarak değerlendirilmiş ve performans düzeyi değişkeninin nitel karakterli firma özelliklerini yansıtan değişkenler ile arasındaki ilişki ortaya çıkarılmıştır. Son olarak ihracat ve inovasyon etkinliği ile anlamlı ilişki içerisinde olan değişkenler ve bunların düzeyleri arasındaki çoklu uyumunun ilişkisi belirlenmiştir. Böylece karar vericilerin, rakiplerine göre firma performanslarındaki olumsuzlukları değerlendirmesini sağlayacak örnek bir çalışma ortaya konulmuştur.

Anahtar Kelimeler: Firma Performansı, İhracat, İnovasyon, Medikal Sektörü
Measurement of Performance of Companies Operating in the Medical Sector and Multi-Compliance Analysis with Qualitative Company Characteristics

\section{Abstract}

Innovative activities and patent applications in the world are commonly carried out in the medical sector. Turkey, in recent years, aims to be able to produce high technology products and also to take part in global markets via an innovative perspective. To reach this aim, it needs the firms operating in the sector to efficiently utilize their sources that would provide their presences, and take a measure by detecting characteristics that may cause inefficiency. In this research scope, the performances of the innovation and export of the firms operating in Samsun's medical sector have been calculated as relative to each other by data envelopment analysis and revealed the relationships between the performance level variables and the variables that reflect the qualitative characteristics. Finally, the multiple-correspondence relation between the variables that are significantly correlated with the export and innovation efficiencies and levels of these variables has been detected. Thus, an example research providing the decision makers evaluating the negatives of their own firm performance has been exhibited.

Keywords: Firm Performance, Export, Innovation, Medical Sector

\section{Giriş}

Küresel rekabetin yoğun yaşandığı günümüz ekonomilerinde firmaların rekabet gücünü kaybetmemeleri ve performanslarını artırabilmeleri için inovasyon odaklı faaliyetler gerçekleştirmeleri bir zorunluluk haline gelmiştir. Zira üretim maliyetlerinin düşmesi, verimliliğin artması

\footnotetext{
${ }^{1}$ Bu çalışma Ondokuz Mayıs Üniversitesi BAP birimi tarafından desteklenen PYO.IKT.1901.16.002 no'lu projeden türetilmiştir.

2 Doç. Dr., Ondokuz Mayıs Üniversitesi, iỉF, İktisat Bölümü. selahattin.kaynak@omu.edu.tr, yazar ORCID bilgisi: https://orcid.org/0000-0003-0082-5961.

3 Dr. Öğr. Üyesi, Ondokuz Mayıs Üniversitesi, iiBF, İktsat Bölümü. mirac.eren@omu.edu.tr, yazar ORCID bilgisi: https://orcid.org/0000-0002-5150-9144.
} 
ve değişen tüketici taleplerinin optimal düzeyde karşılanması firma performansına olumlu katkı sağlayacak inovasyonlarla mümkündür.

İnovasyon ülkelerin ekonomik büyümelerine olumlu katkılar sağladığı gibi firmaların rekabet gücünü artırarak performanslarına pozitif katkı sağlamaktadır. İhracat potansiyelini geliştirmek isteyen firmalar, inovasyonun kaçınılmaz bir süreç olduğunun farkındadırlar (Kaynak vd., 2017).

İnnovatif faaliyetler ve patent başvurularının en çok yapıldığı sektörlerden birisi de medikal sektörüdür. Medikal sektörü sağlık sektörünün hem önemli bileşeni hem de ana girdisidir (Kiper, 2013). Medikal sektörde faaliyet gösteren firmalar; gerçekleştirdikleri Ar-Ge harcamalarının büyüklüğü, patent ve lisans başvurularının sayısı ve sahip oldukları ürün çeşitliliği nedeniyle stratejik öneme sahiptirler. Sektörde daha çok küresel ölçekteki firmalar faaliyet göstermektedir (Kaynak, 2016).

Toplumların gelişmişlik düzeyi ile paralellik arz eden medikal sektörünün büyüme trendi artış göstermektedir. Ayrıca sağlık hizmetlerinin talebinde medikal aletlerin önemli bir faktör olması nedeniyle sağlık hizmetleri için ayrılan kaynakların önemli bir kısmı medikal sektörüne tahsis edilmektedir (Yaylalı vd., 2012). Yüksek düzeyde Ar-Ge harcamaları, inovasyonun sürekliliği ve sahip olunan patentler medikal sektörünün başarısındaki en önemli faktörlerdendir.

Mevcut durumda insanların yaşam koşullarının iyileştirilmesi amacıyla 500.000'den fazla tıbbi teknolojik aygıtlar vardır (MedTech Europe, 2018). Ülkemizde de giderek aratan sağlık harcamalarının büyük bir kısmı ilaç ve tıbbi cihazlar ürünlerine yapılmaktadır (Sağlık Bakanlığı, 2017).

Medikal ürünleri, hastaların tedavi amacıyla sağlık kuruluşlarını tercih etmede en belirleyici faktör haline gelmiştir. Bu cihazlara sahip olan sağlık kuruluşları ile sahip olmayanlar ve üreten ülkeler ile üretmeyen ülkeler arasında farklı bir rekabetçi ortamın oluşmasına neden olmaktadır (Özer vd., 2016: 187).

Medikal sektöründe iyi bir ürün kullanılabilir hale geldikten sonra sadece 18-24 aylık bir yaşam döngüsüne sahip olması, inovasyonun bu sektör için kaçınılmaz olduğunu göstermektedir (MedTech Europe, 2018: 11). 2016 yılında Avrupa Patent Ofisine (Europe Patent Office-EPO) tüm sektörler içerisinde en fazla patent başvurusu (12.263 başvuru sayısı ile) tıbbi teknoloji alanında yapılmıştır. Avrupa'da tıbbi teknoloji sektöründe yaklaşık 27.000 firma faaliyet göstermektedir. Bu firmaların çoğu başta Almanya olmak üzere İngiltere, İtalya, İsviçre, Fransa ve İspanya'da bulunmaktadır (MedTech Europe, 2018: 15).

Dünyada hızla gelişen ve birçok dinamiği bünyesinde barındıran medikal sektörü Türkiye'de genç ve hızlı gelişen bir sektördür. Türkiye son yıllarda medikal sektörü ile ilgili iç piyasada üretilen ürünler ile ihtiyacını karşılayabilmeyi öncelikleyen, yüksek teknoloji içerikli ürünler üretebilen ve innovatif yaklaşımlarla küresel piyasalarda yer alabilen bir ülke olma arzusundadır.

Mevcut durumda Türkiye'de yerli üretim daha çok montaja yönelik ve düşük teknolojik içerikli ürünlerden oluşmaktadır. Sektörde geleneksel ürünler yanında ileri teknoloji içerikli ürünler düzeyinde sınırlı sayıda da olsa üretim yapılmaktadır. Türkiye'de medikal sektörü, sektörde faaliyet gösteren firma sayısı, ürün çeşitliliği kapasitesi ve sahip olduğu pazar büyüklüğü açısından büyüyen ve potansiyeli olan bir sektördür. Medikal ürünlerin üretimi daha çok İstanbul, Ankara, İzmir ve Samsun'da yoğunlaşmıştır. Samsun, özellikle cerrahi el aletleri imalatında önemli bir ivme kazanmış durumdadır. Samsun'da medikal sektörü ilin ekonomik gelişimine katkı sağlayan sektörlerin öncüsü haline gelmiştir. Özellikler cerrahi aletler ile sektörde faaliyet gösteren firmaların çoğu birçok ürünün üretiminde uzmanlaşmışlardır. 
Medikal sektörde faaliyet gösteren firmaların küresel rekabet koşullarında varlık gösterebilmeleri için kaynaklarını etkin bir şekilde kullanmaları gerekmektedir. Günümüz ekonomik yapılarında kaynaklarını etkin kullanılıp kullanılmadığı ise firmaların inovasyon ve ihracat performansları ile ölçülmektedir. Medikal sektörünün bireylerin sağlık boyutuyla ile işkili olması ve küresel piyasalarda sahip olduğu önem nedeniyle diğer sektörlere nispetten farklılık arz etmektedir. Sektörün bu önemine istinaden hazırlanan çalışmada firmaların, inovasyon ve ihracat etkinlikleri ile nitel karakteristikleri arasındaki ilişkinin varlığı ve uyumu analiz edilmiştir.

\section{Firmaların İhracat ve İnovasyon Etkinliklerinin Veri Zarflama Analizi (Data Envelop- ment Analysis-DEA) ile Göreceli Olarak Değerlendirilmesi}

DEA, Karar Verme Birimleri (Decision Making Units-DMUs) için göreceli etkinlik kıyaslaması yapmak için sıkılıkla kullanılan parametrik olmayan bir yöntemdir. Öncelikle 1978 yılında ölçeğe göre sabit getirili (Constant Returns to Scale -CRS) DEA modeli Charnes, Cooper ve Rhodes tarafından ortaya atılmış, ardından 1984 yılında göre değişken getirili (Variable Returns to ScaleVRS) modeli Banker, Charnes ve Cooper tarafından geliştirilmiştir (Cooper, Seiford, \& Zhu). Daha sonraki gelişim sürecinde, katkı modelleri (the Additive Models) ve aylak tabanlı (a SlacksBased Measure of Efficiency-SBM) modeller geliştirilmiştir.

Etkinsiz biçimde işletilen veya çalışma şartları içerisinde dezavantajlı bir konumda olan bir karar birimi etkinsiz olarak ifade edilir. Bunu belirleyebilmek için CRS skorunun VRS skoruna bölünmesi ile elde edilen ölçek etkinliği skoru kullanılır.

Kulanım alanları ve varsayımlara göre çeşitli şekillerde kurulabilmesinin mümkün olduğu DEA modelleri temelde girdi ve çıktı odaklı olmak üzere iki ana gruba ayrılmaktadır. Girdi odaklı modeller, çıktılarının belli bileşiminde etkin olmayan karar birimlerinin etkin konuma gelebilmesi için girdilerinin bileşimlerini ne kadar azaltması gerektiğini ortaya koyarlar. Benzer mantıkla çıktı odaklı modeller, girdilerinin belli bileşiminde etkin olmayan karar birimlerinin etkin konuma gelebilmesi için çıktılarının bileşimlerini ne kadar artırması gerektiğini ortaya koyarlar. CRS varsayımı altında iki yönelimden elde edilen sonuçların aynı olduğu ancak VRS varsayımı altında biraz farklılaştığını gözlemlemek mümkündür. Literatürdeki mevcut çalışmaların çoğunda girdiler öncelikli karar değişkenleri olduğu için genellikle girdi odaklı modellere rastlanmaktadır. Ancak sabit girdi kaynaklarıyla çıktıların düzeylerini olabildiğince yüksek tutma hedefinin olduğu çıktı odaklı çalışmalar da mevcuttur. Ayrıca girdi veya çıktı odaklı olarak kurulamayan durumlar için de toplamsal modeller önerilmiştir (Coelli \& Perelman, 2000).

\section{1. Ölçeğe Göre Sabit Getiri (Constant Return to Scale- CRS) ve Ölçeğe Göre Değişken Getiri (Variable Return to Scale-VRS) modelleri:}

Charnes, Cooper, and Rhodes (1978) tarafından geliştirilen model yazarların baş harfleri olan için CCR modeli olarak adlandırılmaktadır. CCR modeli ölçeğe göre sabit getirili bir model türüdür. Bu modelde, herhangi bir karar biriminin tüm girdilerindeki \%1'lik bir artışın çıktılarında aynı oranda bir değişme sağladığında etkin olarak ifade edilebilir.

Banker, Charnes, and Cooper (1984) tarafından geliştirilen model yazarların baş harfleri olan BCC modeli olarak adlandırılmaktadır. Ölçeğe göre değişken getirili bir model türüdür. Herhangi bir karar biriminin tüm girdilerindeki \%1'lik bir artışın çıktılarında diğer karar birimlerine göre en fazla ya da en az değişme sağladığında etkin olarak ifade edildiği modeldir. Buna göre girdi (çıktı) odaklı-primal (dual) modeller tablodaki gibidir. 
Tablo 1: Girdi (Çıktı) Odaklı-Primal (Dual) DEA Modelleri

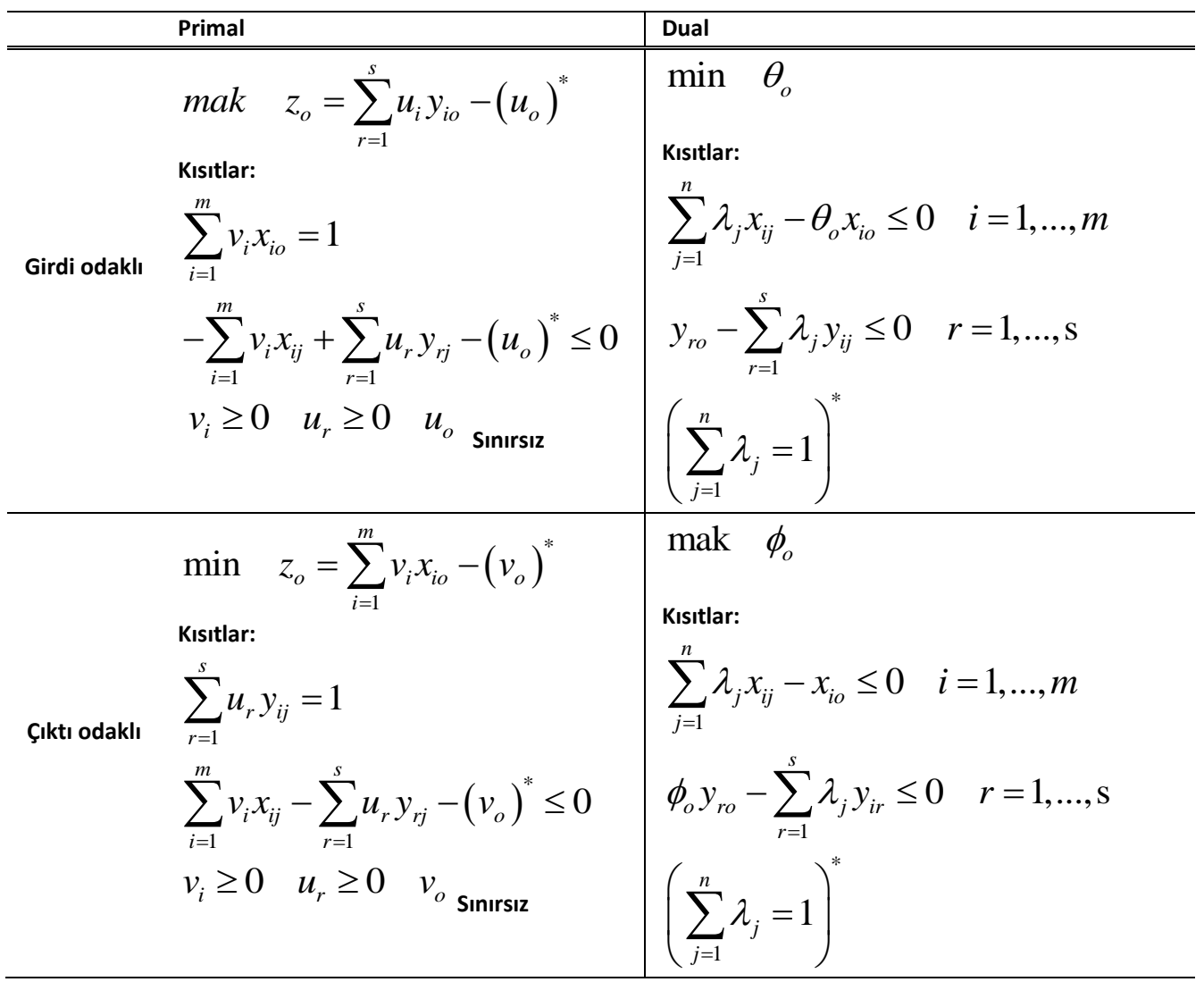

( )* BCC modelde kısıt olarak eklenir.

Burada $y_{r j} \subseteq Y x_{i j} \subseteq X$ olmak üzere $\mathrm{X}, \mathrm{n} \times \mathrm{m}$ boyutunda olup tüm karar birimlerinin girdileri veren matris ve $\mathrm{Y}$ ise $\mathrm{n} \times \mathrm{s}$ boyutunda olup tüm karar birimlerinin çıktılarını veren matristir. $x_{i 0}$ ve $y_{r 0}$ ise sırasıyla $o$. karar biriminin girdi ve çıktılarını veren sırasıyla $\mathrm{m} \times 1$ ve $s \times 1$ boyutlu vektörlerdir. $u_{r}$ ve $v_{i}$ sırasıyla çıktı ve girdilerin ağırlık vektörlerine karşılık gelmektedir. Yine birer skaler değerler olan $\theta_{0}$ ve $\emptyset_{0}, o$. karar biriminin etkinlik skorudur. Her bir karar biriminin etkinlik skor değerlerini elde etmek için kısıtlı denklem sistemi $n$ tane karar birimi için ayrı ayrı çözülür.

\section{2. Ölçek Etkinliği Hesabı}

Bir karar biriminin etkinsiz olmasının sebebinin o karar biriminin etkinsiz faaliyetlerinden mi yoksa çalışma şartları içerisindeki dezavantajlı koşullardan mı kaynaklı olduğunun belirlenebilmesi mümkündür. Ölçeğe göre değişken getiri varsayımı altında kurulan VRS modeli sonucunda üretim olanakları kümesini karar birimlerin konveks kombinasyonları oluşturmaktadır. Bu yüzden VRS skorunun lokal saf teknik etkinliği verdiği kabul edilir. Ölçeğe göre sabit getiri varsayımı altında kurulan CRS modeli sonucunda ise ölçeğe göre sabit getirili üretim olanakları kümesi elde edilir. Bu yüzden CRS skorunun global teknik etkinliği verdiği kabul edilir. Hem CRS hem de VRS skorlarına göre tam etkin olan bir karar birimi en verimli ölçek düzeyinde faaliyet gösterdiği anlaşılmaktadır. Buna karşı VRS skoru tam ve CRS skoru düşükse o karar biriminin lokal olarak 
etkin olduğu; ancak verimsiz ölçek büyüklüğü nedeniyle global olarak etkin olmadığı sonucu sonucuna varılır (Cooper et al., 2011).

Çalışma kapsamında karar birimlerine karşılık gelen sektörde faaliyet gösteren 38 firmanın göreceli ihracat performansının ölçümü için çalışan sayısı, firmaların sahip olduğu belge sayısı ve alınan ulusal/uluslararası hibe ve teşvik sayısı girdi değişkeni, toplam satışlar içerisinde yıllık ortalama ihracat oranları ise çıktı değişkeni olarak belirlenmiştir. İnovatif performansının ölçümü için de çalışan kalifiye eleman sayısı, firmaların sahip olduğu belge sayısı ve alınan ulusal ve uluslararası hibe ve teşvik sayısı girdi değişkeni firmaların marka, patent ve faydalı model varsallığı çıktı değişkeni olarak belirlenmiştir.

Kaynak miktarının sabit tutulup çıktı miktarının mümkün olduğu kadar artırılması hedefi söz konusu olabilmektedir ki bu araştırma kapsamında da durum böyledir. Fakat CRS varsayımı altında yönelimin hiçbir önemi olmayıp elde edilen etkinlik skorları birbirinin çarpmaya göre tersidir. Bu nedenle çalışmada toplam etkinliği ölçmek için girdi odaklı CRS modeli tercih edilmektedir. Buna göre hem ihracat hem de inovasyon için elde edilen etkinlik skorları Tablo 2 ve Tablo 3 'te ifade edilmektedir.

Tablo 2: Ihracat Etkinliği Skorları ve Ölçeğe Göre Getirileri (Girdi Odaklı)

\begin{tabular}{|c|c|c|c|c|}
\hline Firmalar & CRS Etkinlik & VRS Etkinlik & Ölçek Etkinliği & Ölçeğe Göre Getiri \\
\hline Firma01 & 0,155 & 0,500 & 0,310 & Artan \\
\hline Firma02 & 0,184 & 1,000 & 0,184 & Artan \\
\hline Firma03 & 0,155 & 0,500 & 0,310 & Artan \\
\hline Firma04 & 0,197 & 0,333 & 0,592 & Artan \\
\hline Firma05 & 0,276 & 1,000 & 0,276 & Artan \\
\hline Firma06 & 0,138 & 0,400 & 0,344 & Artan \\
\hline Firma07 & 0,184 & 1,000 & 0,184 & Artan \\
\hline Firma08 & 1,000 & 1,000 & 1,000 & Sabit \\
\hline Firma09 & 0,872 & 1,000 & 0,872 & Azalan \\
\hline Firma10 & 0,155 & 0,500 & 0,310 & Artan \\
\hline Firma11 & 0,276 & 1,000 & 0,276 & Artan \\
\hline Firma12 & 0,750 & 0,750 & 1,000 & Sabit \\
\hline Firma13 & 0,184 & 1,000 & 0,184 & Artan \\
\hline Firma14 & 0,276 & 1,000 & 0,276 & Artan \\
\hline Firma15 & 0,155 & 0,500 & 0,310 & Artan \\
\hline Firma16 & 0,184 & 0,500 & 0,367 & Artan \\
\hline Firma17 & 1,000 & 1,000 & 1,000 & Sabit \\
\hline Firma18 & 0,276 & 0,667 & 0,413 & Artan \\
\hline Firma19 & 0,079 & 0,250 & 0,315 & Artan \\
\hline Firma20 & 0,184 & 0,500 & 0,367 & Artan \\
\hline Firma21 & 0,037 & 0,200 & 0,184 & Artan \\
\hline Firma22 & 0,184 & 0,500 & 0,367 & Artan \\
\hline Firma23 & 0,155 & 0,500 & 0,310 & Artan \\
\hline Firma24 & 0,603 & 1,000 & 0,603 & Azalan \\
\hline Firma25 & 0,155 & 0,500 & 0,310 & Artan \\
\hline Firma26 & 0,731 & 0,818 & 0,894 & Azalan \\
\hline
\end{tabular}




\begin{tabular}{lllll}
\hline Firma27 & 0,401 & 0,600 & 0,668 & Azalan \\
Firma28 & 0,872 & 1,000 & 0,872 & Azalan \\
Firma29 & 0,254 & 0,357 & 0,710 & Artan \\
Firma30 & 0,037 & 0,200 & 0,184 & Artan \\
Firma31 & 0,092 & 0,250 & 0,367 & Artan \\
Firma32 & 0,297 & 0,310 & 0,957 & Azalan \\
Firma33 & 0,184 & 1,000 & 0,184 & Artan \\
Firma34 & 0,556 & 1,000 & 0,556 & Azalan \\
Firma35 & 0,254 & 0,286 & 0,888 & Artan \\
Firma36 & 0,508 & 1,000 & 0,508 & Azalan \\
Firma37 & 0,055 & 0,200 & 0,273 & Artan \\
Firma38 & 0,767 & 0,911 & 0,842 & Azalan \\
\hline
\end{tabular}

Girdi odaklı olarak kurulan model sonuçlarına göre 1,00 değerine sahip olan firmaların girdilerine karşılık optimal çıktı düzeylerini elde ettikleri yani etkin birer karar birimi oldukları söylenir. Aksine 1,00 değerinin altında olan firmaların kaynaklarını tam olarak kullanamadığı yani etkinsiz faaliyetlerde bulunduğu sonucu çıkarılır. Tablo 2' ye göre sadece 3 Firma (Firma08, Firma12, Firma17) hem CRS hem de VRS skorlarında 1,00 değerine sahip olup ihracatta diğerlerine göre tam etkin olduğu ve en verimli ölçek büyüklüğünde faaliyet gösterdiği söylenir. Ölçek etkinliğini sağlayan bu firmalar sabit ölçek özelliğine sahiptir. Geriye kalan diğer firmalar içerisinde 12 tanesi VRS skoru 1,00 ve CRS skoru 1,00'in altında çıkmıştır. Buna göre belirtilen firmaların ihracatta etkin faaliyetler sergilediği ancak faaliyet gösterdiği dezavantajlı koşullardan (yönetim dışındaki coğrafi konum, iklim, vs. gibi dış etkilerden) dolayı potansiyellerini kullanamadıkları yani ölçek etkinliğini yakalayamadıkları sonucu çıkmaktadır. 23 firmanın her iki skorunun 1,00 'in altında kaldığı gözlemlenmektedir. Bunun anlamı ise hem firmaların etkinsiz yönetimsel faaliyetlerinin hem de dezavantajlı koşullarının mevcut olmasıdır.

Tablo 2'ye göre ihracatta ölçek etkinlik skoru 1,00 altında olan (ölçek etkinliğini yakalayamayan) firmalar içerisinde 16 tanesi ölçeğe göre artan getiri özelliğini sergilemektedir. Yani firmaların ihracat düzeylerinin oransal artışı girdi öğelerinin oransal artışından daha büyüktür. Bunun sebebi, işin ölçeği büyüdükçe daha yoğun bir işbölümü ve uzmanlaşmanın olurlu hale gelmesidir. 19 firma ise ölçeğe göre azalan getiri sergilemektedir. Yani bu firmaların ihracat düzeylerinin oransal artışı girdi öğelerinin oransal artıştan daha küçüktür. Bunun sebebi, çalışma ölçeğindeki büyüme ile birlikte ortaya çıkabilecek iletişim ve koordinasyon sorunlarından dolayı işin etkin biçimde yürütülmesinin zorlaşmasıdır.

Genel anlamda çok küçük üretim ölçeğindeki bir firmanın ölçeğe göre artan getirili bir yapı ile karşı karşıyadır. Ölçeğe göre artan getiri, çalışma ölçeği büyüdükçe önce sabit getiriye sonra da azalan getiriye dönüşür. 
Tablo 3: Inovasyon Etkinliği Skorları ve Ölçeğe Göre Getirileri (Girdi Odaklı)

\begin{tabular}{|c|c|c|c|c|}
\hline Firmalar & CRS Etkinlik & VRS Etkinlik & Ölçek Etkinliği & Ölçeğe Göre Getiri \\
\hline Firma01 & 0,000 & 0,500 & 0,000 & Artan \\
\hline Firma02 & 1,000 & 1,000 & 1,000 & Sabit \\
\hline Firma03 & 0,500 & 0,598 & 0,836 & Artan \\
\hline Firma04 & 1,000 & 1,000 & 1,000 & Sabit \\
\hline Firma05 & 0,000 & 1,000 & 0,000 & Artan \\
\hline Firma06 & 0,375 & 0,526 & 0,713 & Artan \\
\hline Firma07 & 0,000 & 1,000 & 0,000 & Artan \\
\hline Firma08 & 0,000 & 1,000 & 0,000 & Artan \\
\hline Firma09 & 0,200 & 0,240 & 0,833 & Artan \\
\hline Firma10 & 0,000 & 0,500 & 0,000 & Artan \\
\hline Firma11 & 0,000 & 1,000 & 0,000 & Artan \\
\hline Firma12 & 0,476 & 0,484 & 0,984 & Artan \\
\hline Firma13 & 0,000 & 1,000 & 0,000 & Artan \\
\hline Firma14 & 0,000 & 1,000 & 0,000 & Artan \\
\hline Firma15 & 0,000 & 0,500 & 0,000 & Artan \\
\hline Firma16 & 1,000 & 1,000 & 1,000 & Sabit \\
\hline Firma17 & 1,000 & 1,000 & 1,000 & Sabit \\
\hline Firma18 & 1,000 & 1,000 & 1,000 & Sabit \\
\hline Firma19 & 0,563 & 0,607 & 0,926 & Artan \\
\hline Firma20 & 1,000 & 1,000 & 1,000 & Sabit \\
\hline Firma21 & 0,600 & 0,600 & 1,000 & Sabit \\
\hline Firma22 & 0,000 & 0,500 & 0,000 & Artan \\
\hline Firma23 & 0,500 & 0,508 & 0,985 & Artan \\
\hline Firma24 & 0,500 & 0,500 & 1,000 & Sabit \\
\hline Firma25 & 0,000 & 0,500 & 0,000 & Artan \\
\hline Firma26 & 1,000 & 1,000 & 1,000 & Sabit \\
\hline Firma27 & 0,375 & 0,375 & 1,000 & Sabit \\
\hline Firma28 & 0,200 & 0,208 & 0,961 & Artan \\
\hline Firma29 & 0,000 & 0,286 & 0,000 & Artan \\
\hline Firma30 & 0,600 & 0,600 & 1,000 & Sabit \\
\hline Firma31 & 0,529 & 0,545 & 0,971 & Azalan \\
\hline Firma32 & 0,400 & 0,400 & 1,000 & Sabit \\
\hline Firma33 & 0,000 & 1,000 & 0,000 & Artan \\
\hline Firma34 & 0,316 & 0,337 & 0,938 & Artan \\
\hline Firma35 & 0,316 & 0,349 & 0,904 & Artan \\
\hline Firma36 & 0,500 & 0,500 & 1,000 & Sabit \\
\hline Firma37 & 0,400 & 0,400 & 1,000 & Sabit \\
\hline Firma38 & 0,750 & 0,783 & 0,958 & Azalan \\
\hline
\end{tabular}

Tablo 3'e göre sadece 12 Firma hem CRS hem de VRS skorlarında 1,00 değerine sahip olup inovasyonda diğerlerine göre tam etkin olduğu ve en verimli ölçek büyüklügünde faaliyet gösterdiği söylenir. Ölçek etkinliğini sağlayan bu firmalar sabit ölçek özelliğine sahiptir. Geriye kalan diğer firmalar içerisinde 7 tanesi VRS skoru 1,00 ve CRS skoru 1,00'in altında çıkmıştır. Buna 
göre belirtilen firmaların inovasyonda etkin faaliyetler sergilediği ancak faaliyet gösterdiği dezavantajlı koşullardan (yönetim dışındaki coğrafi konum, iklim, vs. gibi dış etkilerden) dolayı potansiyellerini kullanamadıkları yani ölçek etkinliğini yakalayamadıkları sonucu çıkmaktadır. 19 firmanın her iki skorunun 1,00'in altında kaldığı gözlemlenmektedir. Bunun anlamı ise hem firmaların etkinsiz yönetimsel faaliyetlerinin hem de dezavantajı koşullarının mevcut olmasıdır.

Tablo 3'e göre inovasyon ölçek etkinlik skoru 1,00 altında olan (ölçek etkinliğini yakalayamayan) firmalar içerisinde 24 tanesi ölçeğe göre artan getiri özelliğini sergilemektedir. Yani firmaların inovasyon düzeylerinin oransal artışı girdi öğelerinin oransal artışından daha büyüktür. İşin ölçeği büyüyünce, daha yoğun bir işbölümü ve uzmanlaşmanın olurlu hale gelmesi, bunun ortaya çıkma nedeni olarak gösterilmektedir. 2 firma ise ölçeğe göre azalan getiri sergilemektedir. Yani bu firmaların inovasyon düzeylerinin oransal artışı girdi öğelerinin oransal artıştan daha küçüktür. Bunun ortaya çıkma nedeni çalışma ölçeğindeki büyümeye bağlı olarak oluşacak iletişim bozuklukları sebebiyle işi etkin bir biçimde yürütmenin adım adım zorlaşmasıdır. Buradan çoğu firmanın inovasyonda küçük üretim ölçeklerinde olduğu ortaya çıkmaktadır.

Ortaya çıkan bir başka sonuç ise hem ihracatta hem de inovasyonda diğer firmalara göre göreceli olarak en iyi performansı sergileyen 1 tane firma (Firma17) olduğudur.

\section{Firmaların İnovasyon ve İhracat Etkinlikleri İle Nitel Karakteristikleri Arasındaki iliş̧ki}

Medikal sektöründeki firmaların hem ihracat hem de inovasyon performansları bakımından birbiri içerisinde göreceli olarak değerlendirilmesinin ardından firmaları global etkinlik skoruna göre "Etkin" ve "Etkinsiz" biçiminde iki gruba ayırmak mümkündür. Böylece ihracat ve inovasyon performansı değişkenleri ordinal (sıralı) ölçekte ölçülebilir hale gelir. Samsun medikal sektörü envanter anketine göre elde edilen nitel karakterli firma özelliklerini yansıtan değişken grubu ile yine nitel ölçek haline getirilen performans değişkenleri arasında ilişki bulunup bulunmadığını incelemek için ki-kare bağımsızlık testinden yararlanılabilir. Böylece değişkenler arasında bağımsızlık olup olmadığı ortaya konulması mümkündür. Buna göre ihracat ve inovasyon global etkinlik değişkenleri ile firma özelliklerini yansıtan değişken grubu arasındaki ilişkilerin ki kare analizi aşağıda yer alan tablolarda gösterilmektedir.

Tablo 4: Ihracat ve Inovasyon Etkinliği ile Firma Özellikleri Arasındaki Ki-Kare Bağımsızlık Testi Sonuçları

\begin{tabular}{llcc}
\hline & & $\begin{array}{c}\text { ihracatın Global Teknik Etkin- } \\
\text { liği-Girdi Odaklı }\end{array}$ & $\begin{array}{c}\text { inovasyonun Global Teknik } \\
\text { Etkinliği-Girdi Odaklı }\end{array}$ \\
\hline \hline \multirow{2}{*}{ Firmaların hukuki yapısı } & Ki-Kare & 19,950 & 9,164 \\
& p-Olasılık Değeri &, $000^{*, b, c}$ & $, 027^{*}, \mathrm{~b}, \mathrm{c}$ \\
\hline \multirow{2}{*}{ Firmaların yönetim durumu } & Ki-Kare &, 181 &, 735 \\
& p-Olasılık Değeri &, $671^{\mathrm{b}, \mathrm{c}}$ &, $391^{\mathrm{b}, \mathrm{c}}$ \\
\hline \multirow{2}{*}{ Üretim yapılan yer } & Ki-Kare & 1,900 & 4,976 \\
& p-Olasılık Değeri &, $754^{\mathrm{b}, \mathrm{c}}$ &, $290^{\mathrm{b}, \mathrm{c}}$ \\
\hline \multirow{2}{*}{ Üretilen / satılan ürün niteliği } & Ki-Kare &, 455 & 3,317 \\
& P-Olasılık Değeri &, $500^{\mathrm{b}, \mathrm{c}}$ &, $069^{*, \mathrm{~b}}$ \\
\hline Pazarlama ve dağıtım kanalla- Ki-Kare & 9,349 & 17,878 \\
rında kullanılan yöntemler & p-Olasılık Değeri &, $096^{*, \mathrm{~b}, \mathrm{c}}$ &, $003^{*, \mathrm{~b}, \mathrm{c}}$ \\
\hline Otomasyon (bilişim) sisteminin & Ki-Kare &, 754 & 3,065 \\
varlığı & p-Olasılık Değeri &, $385^{\mathrm{b}, \mathrm{c}}$ &, $080^{*, \mathrm{~b}}$ \\
\hline
\end{tabular}


Aralık 2018, C. 13, S. 3

\begin{tabular}{|c|c|c|c|}
\hline \multirow{2}{*}{ Üretim teknolojisi } & Ki-Kare & 860 & 001 \\
\hline & p-Olasılık Değeri &, $354^{b, c}$ & $981^{\mathrm{b}}$ \\
\hline \multirow{2}{*}{ Teknolojisi sınıflaması } & Ki-Kare & 3,619 & ,640 \\
\hline & p-Olasılık Değeri &, $306^{b, c}$ &, $887^{\mathrm{b}, \mathrm{c}}$ \\
\hline \multirow{2}{*}{ Kapasite kullanım oranları } & Ki-Kare & 2,608 & 8,192 \\
\hline & p-Olasılık Değeri &, $271^{\mathrm{b}, \mathrm{c}}$ &, $017^{*, b, c}$ \\
\hline \multirow{2}{*}{ Çalışan genel eğitim durumları } & Ki-Kare & 3,460 & 15,079 \\
\hline & p-Olasılık Değeri &, $629^{b, c}$ & $, 010^{*}, \mathrm{~b}, \mathrm{c}$ \\
\hline \multirow{2}{*}{$\begin{array}{l}\text { Personele uygulanan ücretlen- } \\
\text { dirme sistemi }\end{array}$} & Ki-Kare & 1,103 & ,505 \\
\hline & p-Olasılık Değeri &, $576^{\mathrm{b}, \mathrm{c}}$ &, $777^{\mathrm{b}}$ \\
\hline \multirow{2}{*}{$\begin{array}{l}\text { Personele uygulanan teşvik sis- } \\
\text { temi }\end{array}$} & Ki-Kare & 3,333 & 3,655 \\
\hline & p-Olasılık Değeri &, $343^{b, c}$ &, $301^{b, c}$ \\
\hline \multirow{2}{*}{$\begin{array}{l}\text { Danışmanlık hizmeti alınması } \\
\text { durumu }\end{array}$} & Ki-Kare & 2,111 & 175 \\
\hline & p-Olasılık Değeri & $146^{b, c}$ &, $676^{\mathrm{b}}$ \\
\hline \multirow{2}{*}{$\begin{array}{l}\text { İnsan kaynakları ve muhasebe } \\
\text { bölümü varlığı }\end{array}$} & Ki-Kare & ,234 & 121 \\
\hline & p-Olasılık Değeri &, $629^{b, c}$ &, $728^{b}$ \\
\hline \multirow{2}{*}{$\begin{array}{l}\text { Personele hizmet içi eğitim ve- } \\
\text { rilmesi durumu }\end{array}$} & Ki-Kare & 9,349 & 3,410 \\
\hline & p-Olasılık Değeri &, $002^{*, b, c}$ & $, 065^{*}, \mathrm{~b}$ \\
\hline \multirow{2}{*}{$\begin{array}{l}\text { Profesyonel yönetici istihdam } \\
\text { edilmesi durumu }\end{array}$} & Ki-Kare &, 563 & ,236 \\
\hline & p-Olasılık Değeri &, $453^{\mathrm{b}, \mathrm{c}}$ &, $627^{\mathrm{b}}$ \\
\hline \multirow{2}{*}{$\begin{array}{l}\text { Kalite-kontrol ve ar-ge amaçlı la- } \\
\text { boratuvarınız varlığı }\end{array}$} & Ki-Kare & 974 & ,036 \\
\hline & p-Olasılık Değeri &, $324^{b, c}$ & $850^{\mathrm{b}}$ \\
\hline \multirow{2}{*}{ Ürünlerin satış yöntemleri } & Ki-Kare & 1,377 & 1,493 \\
\hline & p-Olasılık Değeri &, $502^{\mathrm{b}, \mathrm{c}}$ &, $474^{\mathrm{b}, \mathrm{c}}$ \\
\hline \multirow{2}{*}{$\begin{array}{l}\text { KOSGEB veri tabanına kayıt du- } \\
\text { rumu }\end{array}$} & Ki-Kare & 117 & 477 \\
\hline & p-Olasılık Değeri &, $732^{\mathrm{b}, \mathrm{c}}$ &, $490^{\mathrm{b}, \mathrm{c}}$ \\
\hline \multirow{2}{*}{$\begin{array}{l}\text { Üniversite ile ortak herhangi bir } \\
\text { çalışma yapılması durumu }\end{array}$} & Ki-Kare & 396 & ,015 \\
\hline & p-Olasılık Değeri &, $529^{b, c}$ &, $904^{\mathrm{b}}$ \\
\hline \multirow{2}{*}{$\begin{array}{l}\text { Yatırım teşviklerinden yararla- } \\
\text { nılması durumu }\end{array}$} & Ki-Kare & 655 & ,419 \\
\hline & p-Olasılık Değeri &, $418^{\mathrm{b}, \mathrm{c}}$ &, $517^{b}$ \\
\hline \multirow{2}{*}{$\begin{array}{l}\text { Yabancı şirketlerle stratejik iş- } \\
\text { birliğin durumu }\end{array}$} & Ki-Kare & 655 & 113 \\
\hline & p-Olasılık Değeri &, $418^{\mathrm{b}, \mathrm{c}}$ &, $736^{\mathrm{b}}$ \\
\hline
\end{tabular}

*. Ki Kare istatistiği \%10 düzeyinde anlamlıdır.

b. Bu alt tablodaki hücrelerin \%20'sinden fazlası 5'den daha az beklenen hücre sayılarına sahiptir.

c. Bu alt tablodaki beklenen hücre sayısı 1'den daha küçüktür.

b. ve c. deki özel durumdan dolayı Pearson Ki-Kare test değeri geçersiz olabileceğinden çapraz (kontenjans) tablo gözelerdeki teorik frekansların herhangi biri 5 ten küçük ise uygulanan Fisher Ki Kare (Fisher's Exact Test) sonuçları verilmiştir.

Bağımsızlık testinde aşağıdaki hipotezler test edilir:

Ho: Değişkenler birbirinden bağımsızdır. / Bağımsızlık vardır.

H1: Değişkenler birbirinden bağımsız değildir. / Bağımsızlık yoktur. 
Ki-kare test istatistiğinin p-olasılık değerlerinin daha önceden belirlenen \%10 anlamlılık seviyesinden (hata payından) küçük olması durumuna göre HO hipotezinin reddedilmesi ve H1 hipotezinin doğruluğunun kabul edilmesi durumuna göre elde edilen bulgular yorumlanırsa; firmaların hukuki yapısı, pazarlama ve dağıtım kanallında kullandıkları yöntemler ve personele hizmetiçi eğitim verilmesi durumunun hem ihracat hem de inovasyon etkinlikleri ile arasında bir anlamlı bağımlılığın bir ilişkinin olduğu söylenebilir.

Üretilen/satılan ürün niteliği, otomasyon (bilişim) sisteminin varlığı, kapasite kullanım oranları ve çalışanların genel eğitim durumları ile inovasyon etkinliği arasında anlamlı bir bağımlılığın bir ilişkinin olduğu söylenebilir. Birden fazla seçeneğin söz konusu olduğu çoktan seçmeli sorular için Ki - Kare bağımsızlık testi Tablo 5'teki gibidir.

Tablo 5: ihracat ve Inovasyon Etkinliği ile Firma Özellikleri Arasındaki Ki-Kare Bağımsızlık Testi Sonuçları (çoktan seçmeli sorular için)

\begin{tabular}{|c|c|c|c|}
\hline & & $\begin{array}{l}\text { İhracatın Global Teknik } \\
\text { Etkinliği-Girdi Odaklı }\end{array}$ & $\begin{array}{l}\text { İnovasyonun Global Teknik } \\
\text { Etkinliği-Girdi Odaklı }\end{array}$ \\
\hline \multirow{2}{*}{$\begin{array}{l}\text { Farklı kuruluşlardan alınan hibe, teşvik } \\
\text { desteği }\end{array}$} & Ki-Kare & 34,847 & 7,588 \\
\hline & p-Olasılık Değeri & $, 000^{*}, \mathrm{~b}, \mathrm{c}$ &, $270^{\mathrm{b}, \mathrm{c}}$ \\
\hline \multirow{2}{*}{$\begin{array}{l}\text { Hizmet içi eğitim imkânın sağlanma } \\
\text { türü }\end{array}$} & Ki-Kare & & 4,549 \\
\hline & p-Olasılık Değeri & & $208^{b}$ \\
\hline \multirow{2}{*}{ Hammadde ve tedarikçi durumu } & Ki-Kare & 2,646 & 3,159 \\
\hline & p-Olasılık Değeri &, $619^{b, c}$ &, $532^{\mathrm{b}}$ \\
\hline \multirow{2}{*}{$\begin{array}{l}\text { Kuruluş aşamasında kuruluş sermayesi } \\
\text { dışında kullanılan finans kaynakları }\end{array}$} & Ki-Kare & 1,259 & 1,170 \\
\hline & p-Olasılık Değeri & ,739 b,c &, $760^{\mathrm{b}}$ \\
\hline
\end{tabular}

*. Ki Kare istatistiği \%10 düzeyinde anlamlıdır.

b. Bu alt tablodaki hücrelerin \%20'sinden fazlası 5'den daha az beklenen hücre sayılarına sahiptir.

c. Bu alt tablodaki beklenen hücre sayısı 1'den daha küçüktür.

b. Ve c. Deki özel durumdan dolayı Pearson Ki-Kare test değeri geçersiz olabileceğinden çapraz (kontenjans) tablo Gözelerdeki teorik frekansların herhangi biri 5 ten küçük ise uygulanan Fisher Ki Kare (Fisher's Exact Test) sonuçları verilmiştir.

Birden fazla seçeneğin söz konusu olduğu çoktan seçmeli sorular için ihracat etkinliği ile farklı kuruluşlardan alınan hibe teşvik desteği arasında anlamlı bir ilişki olduğunu söylemek mümkündür. Hangi hibe teşvik desteği veya desteklerinde anlamlı ilişkinin ortaya çıktığını belirlemek için her bir faktör ayrı bir değişken olarak ifade edilerek elde edilen Ki-kare bağımsızlık testi sonuçları Tablo 6'daki gibidir. 
Tablo 6: Farklı Kuruluşlardan alınan Hibe, Teşvik desteği ile ihracat etkinliği arasındaki Ki-Kare Bağımsızlık Testi Sonuçları

\begin{tabular}{llc}
\hline & & \multicolumn{1}{c}{$\begin{array}{c}\text { Ihracatın Global Teknik } \\
\text { Etkinliği-Girdi Odaklı }\end{array}$} \\
\hline \hline KOSGEB'den hibe, teşvik desteği alınması durumu & Ki-Kare & 3,237 \\
\hline TUBiTAK'dan hibe, teşvik desteği alınması durumu & P-Olasılık Değeri & 0,117 \\
\hline \multirow{2}{*}{ BANKALAR'dan hibe, teşvik desteği alınması durumu } & Ki-Kare &, $732^{\mathrm{b}, \mathrm{c}}$ \\
\hline \multirow{2}{*}{ OKA'dan hibe, teşvik desteği alınması durumu } & P-Olasılık Değeri & 0,181 \\
\hline \multirow{2}{*}{ Ekonomi Bakanlığı'ndan hibe, teşvik desteği alınması durumu } & Ki-Kare &, $671^{\mathrm{b}, \mathrm{c}}$ \\
\hline \multirow{2}{*}{ Diğer kuruluşlardan hibe, teşvik desteği alınması durumu } & P-Olasılık Değeri & 0,563 \\
\hline
\end{tabular}

*. Ki Kare istatistiği \%10 düzeyinde anlamlıdır.

b. Bu alt tablodaki hücrelerin \%20'sinden fazlası 5'den daha az beklenen hücre sayılarına sahiptir.

c. Bu alt tablodaki beklenen hücre sayısı 1'den daha küçüktür.

b. Ve c. Deki özel durumdan dolayı Pearson Ki-Kare test değeri geçersiz olabileceğinden çapraz (kontenjans) tablo Gözelerdeki teorik frekansların herhangi biri 5 ten küçük ise uygulanan Fisher Ki Kare (Fisher's Exact Test) sonuçları verilmiştir.

Tablo 6’ya göre P-olasılık değerlerinin \%10'dan küçük olması nedeniyle KOSGEB ve Diğer kuruluşlardan hibe teşvik alınıp alınmaması durumunun ihracat etkinliği ile anlamlı bir ilişki içerisinde oldukları gözlemlenmektedir.

\section{Firmaların İnovasyon ve ỉhracat Etkinlikleri İle Nitel Firma Karakteristikleri Arasındaki iliş̧kinin Çoklu Uyum Analizi}

Gözlem birimlerinin kategorik olarak ölçüldügü veya ölçüldükten sonra kategorik hale getirildiği değişkenlerin bağımlılık veya bağımsızlığının analizinde ki-kare testleri yaygın bir şekilde kullanılmaktadır. Ancak, bu istatistiki analiz tekniğin kullanılabilmesi birtakım şartlara (örneğin teorik frekanslardan herhangi biri 5 ile 25 arasında ise Yates Ki Kare -Continuity Correction veya teorik frekansların herhangi biri 5 ten küçük ise Fisher Ki Kare-Fisher's Exact Test uygulanması) bağlıdır. Bu tür istatistiklerin gerektirdiği şartlar dahi ortaya çıkarılan bilgi çok genel olmakta ve sonuçların yorumlanmasında zorluklara neden olabilmektedir (Baspinar \& Mendes, 2000). Bu teknikle değişkenler arası ve ayrıca değişkenlerin düzeyleri arasındaki mevcut olan ilişkilerin daha detaylı bir biçimde meydana getirilmesi ve elde edilen çıktıların görsel olarak sunulabilmesi pek olası değildir (Devillers \& Karcher, 2013; Mendeş, 2002). Söz konusu problemleri uyum analizi tekniği ile aşmak mümkündür.

Uyum analizi (Correspondence analysis; CA); iki ya da daha fazla yönlü çapraz (kontenjans) tablo haline getirilebilen kategorik ya da elde edildikten sonra kategorik hale dönüştürülmüş bir veri matrisini daha az boyutlu bir uzayda satır ve sütunları noktalarla ifade edilen grafiksel gösterim şekline dönüştüren açıklayıcı çok değişkenli bir analiz tekniğidir (Greenacre \& Hastie, 1987). 
Uyum analizinin en basit hali olan "basit uyum analizi" , iki yönlü kontenjans tablolarının, "homojenlik analizi" (Homogenite Analysis; HA) olarak da adlandırılan "çoklu uyum analizi (Multiple Correspondence Analysis; MCA)" ise ikiden fazla yönlü kontenjans tablolarının analizi için kullanılmaktadır (Greenacre \& Hastie, 1987).

Birinci aşamada, ihracat etkinliği ile anlamlı ilişki içerisinde olan değişkenler (faktörler) ve bunların kategorileri (düzeyleri) arasındaki çoklu uyumunun ölçmesi amaçlanmaktadır. Bunun için R 3.3.2 paket programı ile yapılan analiz sonucunda, dikkate alınan değişkenlerin kategorileri için var olan değişimin (varyasyonun) ortalama ölçüsü biçiminde ifade edilen toplam değişim (inertia) içerisinde her bir boyuta düşen değişimin miktarları Tablo 7'de gösterilmektedir.

Tablo 7: Boyutların Toplam Değişimi Açıklama Oranları

\begin{tabular}{cccc}
\hline \multirow{2}{*}{ Boyutlar } & Varyans Inertia (Değişim) & \multicolumn{2}{c}{ Boyutların toplam değişimi açıklama oranları } \\
\cline { 3 - 4 } & & \% Varyans (Açıklama payı) & Birikimli \% Varyans (Eklemeli pay) \\
\hline \hline 1 & 0,477 & 23,870 & 23,870 \\
3 & 0,293 & 14,635 & 38,505 \\
4 & 0,243 & 12,131 & 50,636 \\
5 & 0,211 & 10,531 & 61,166 \\
6 & 0,179 & 8,962 & 70,128 \\
7 & 0,153 & 7,657 & 77,785 \\
8 & 0,130 & 6,485 & 84,270 \\
9 & 0,109 & 5,427 & 89,697 \\
10 & 0,092 & 4,625 & 94,322 \\
11 & 0,077 & 3,843 & 98,164 \\
12 & 0,037 & 1,836 & 100,000 \\
\hline
\end{tabular}

- Olası boyut sayısı=kategori sayısı-değişken sayısı=18-6=12

Doğrusal regresyona benzer bir mantıkla çoklu uyum analizinde de boyutlar tarafından açıklanan varyansla ilgilenilir. Çok boyutlu ölçeklemede inertia, varyans yerine kullanılan bir kavram olup nitel karakterdeki değişkenler arasındaki ilişkinin belirlenmesinde kullanılan $\chi 2$ değerinin gözlem sayısına oranlanması ile elde edilir (Greenacre \& Blasius, 2006; Williams, Abdi, French, \& Orange, 2010).

Düşük boyutlu çözümlemeye göre birbirine yakın iki nokta yüksek boyutlu çözümlemeye göre birbirinden daha uzakta kalabilmektedir. Dolayısıyla, boyut sayısının artması yorumsal farklılara yol açabildiği için yorumlamayı kolaylaştırmak adına olabildiğince daha az boyut yeğlenir.Buna karşın, açıklanan inertianın boyutlara paylaşımının yüksek oranda olacağı bir çözüm sonucunun bulunabilmesi dikkat edilmesi gereken bir başka husustur. Bu nedenle yorumlanacak boyut sayısının belirlenmesinde iki yol önerilmiştir. Bunlardan birincisi, boyut sayılarının yatay eksende özdeğerlerin düşey eksende olduğu azalan histogram yapıda bir grafik için ilk kırılma noktasına kadar olan boyutlar, ikincisi ise olası değişken kategori sayısı p olmak üzere $1 / p$ değerini aşan inertiaya sahip boyutlar yorumlanacak uygun boyut sayılarını oluşturmaktadır (Gifi, 1990; Greenacre \& Hastie, 1987). Diğer yandan özellikle ele alınan değişken sayılarının 5'i geçmesi durumunda, boyutların değişimi açıklamadaki paylarının küçük olması yorumlama aşamasında bazı güçlüklere neden olmaktadır. 
Açıklanan inertianın boyutlara paylaşımının yüksek oranda olacağı bir çözüm sonucunun bulunabilmesi dikkat edilecek bir başka husustur. Tablo 7'de de görülebileceği gibi, en yüksek açıklama oranına sahip olan \% 23,870'lik oranla birinci boyuttur.

Açıklama oranları diğer boyutlarda adım adım düşmektedir. Toplam değişimi açıklamada ilk iki boyutun payının \%38,505 olduğu gözlemlenmektedir. Bir başka deyişle, bir uyum analizi çözümlemesi 12 boyutlu uzaydan 2 boyutlu uzaya indirgendiğinde toplam değişimin ancak \%28,505'lik kısmı açıklanmaktadır. Bu değişkenlerin kategorileri arasındaki ilişkilerin iki boyutlu bir uzayda gösterilmesi, toplam değişimi açıklama bakımından çok da yeterli değildir. Ancak açıklanan inertianın ilk iki boyuta paylaşımının diğerlerinden daha yüksek olması durumundan ötürü bu çalışmada elde edilen sonuçların yorumlanmasını göstermek amacıyla sadece iki boyut dikkate alınmıştır. Burada önemli olan husus iki boyutlu uzayı açıklayan inertianın bu boyutlara paylaşımının yüksek oranda olacağı bir çözüm sunmaktır. Bunun için yapılması gereken yollardan birisi ise değiş̧enler ve MCA ana boyutları arasındaki korelasyonu görselleştirerek karar vermektir. Buna göre;

Şekil 1: Değişkenler ve Temel Boyutlar Arasındaki Korelasyon

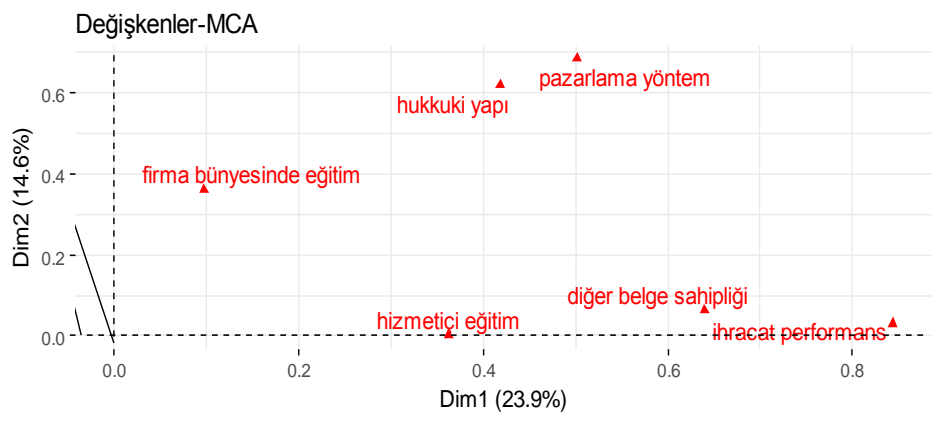

Şekil 1, her bir boyutla en fazla ilişkili olan değişkenleri belirlemeye yardımcı olmaktadır. Değişkenler ve boyutlar arasındaki karesel korelasyonlar koordinatlar olarak kullanılmaktadır. Buradan ihracat performansı ve diğer belge sahipliği değişkenlerinin 1. Boyutla ve pazarlama yöntemi ve hukuki yapı değişkeninin hem 1 . Boyutla hem de 2 . Boyutla en çok ilişkili olduğu gözlemlenebilir.

İhracat etkinliği ile anlamlı ilişki içerisinde olan değişkenler (faktörler) ve bunların kategorileri (düzeyleri) arasındaki uyumun daha belirgin ölçmesi için değişken azaltımına gidildiğine toplam değişim (inertia) içerisinde her bir boyuta düşen değişimin miktarları Tablo 8'de gösterilmektedir. 
Eskişehir Osmangazi Üniversitesi ïBF Dergisi

Tablo 8: Boyutların Toplam Değişimi Açıklama Oranları

\begin{tabular}{cccc}
\hline \multirow{2}{*}{ Boyutlar } & Varyans Inertia (Değişim) & \multicolumn{2}{c}{ Boyutların toplam değişimi açıklama oranları } \\
\cline { 3 - 4 } & & \% Varyans (Açıklama payı) & Birikimli \% Varyans (Eklemeli pay) \\
\hline 1 & 0,627 & 25,090 & 25,090 \\
2 & 0,394 & 15,750 & 40,840 \\
3 & 0,334 & 13,379 & 54,219 \\
4 & 0,282 & 11,286 & 65,505 \\
5 & 0,250 & 10,000 & 75,505 \\
6 & 0,229 & 9,157 & 84,662 \\
7 & 0,165 & 6,585 & 91,247 \\
8 & 0,143 & 5,714 & 96,961 \\
9 & 0,076 & 3,039 & 100,000 \\
10 & 0,000 & 0,000 & 100,000 \\
\hline
\end{tabular}

Boyutları açıklama ilişkisi düşük olan değişkenler atıldığında kalan değişkenler ile yapılan uyum analizinde ilk iki boyuttaki toplam değişimin açıklanan kısmı artmıştır. Böylece elde edilen değişken kategorileri arasındaki uyum Şekil 2'deki gibidir.

Şekil 2: Değişken Kategorileri ve ihracat Etkinliğinin Çoklu Uyum Analizi Serpilme Diyagramı

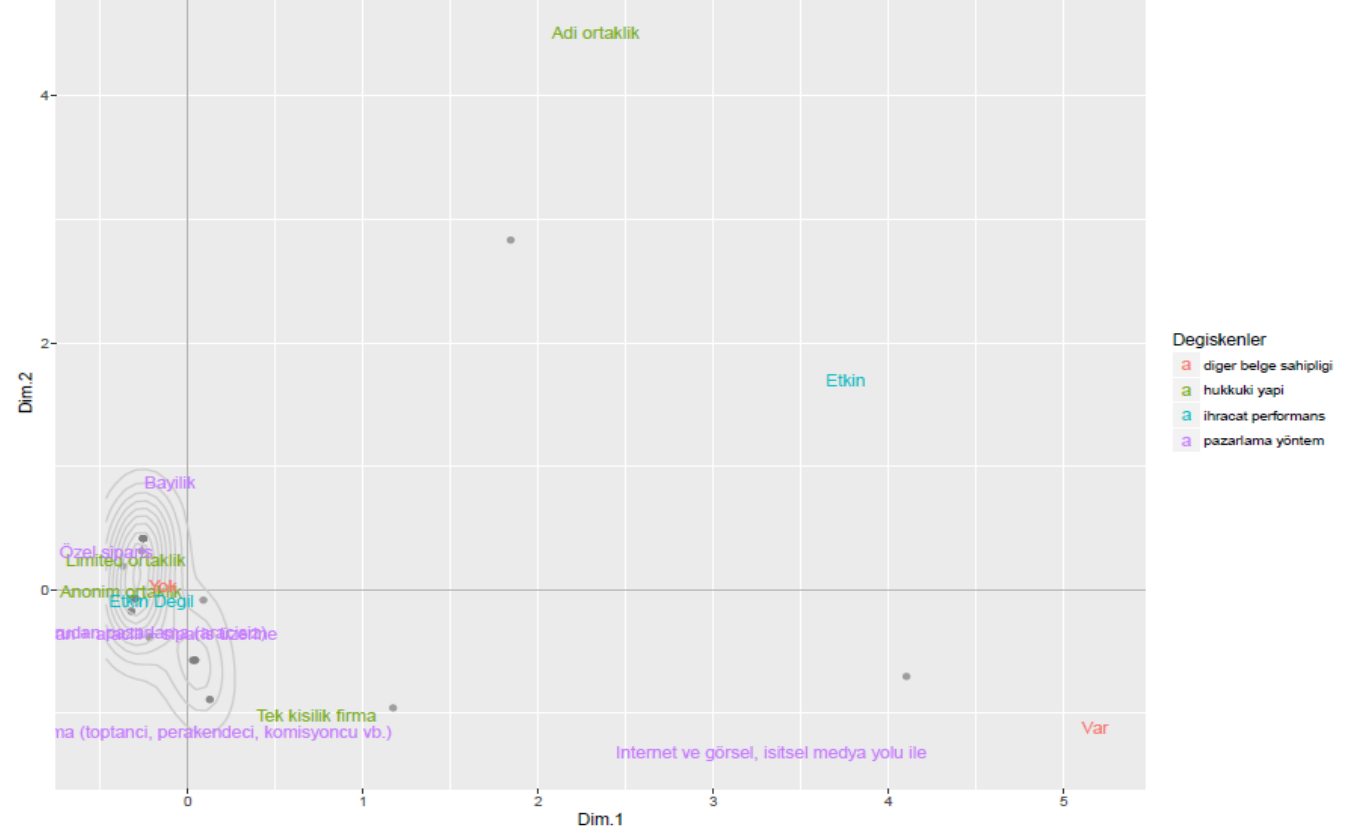

Elde edilen bulgulara göre; göreceli olarak ihracat etkinliğini yakalayamayan firmaların pazarlama ve dağıtım yöntemlerinde internet görsel, işitsel medyayı kullanmadıkları, herhangi bir kuruluştan hibe teşvik desteği almadıkları, limited ve anonim ortaklıklar olduğu gözlemlenmektedir. 
İkinci aşamada, inovasyon etkinliği ile anlamlı ilişki içerisinde olan değişkenler (faktörler) ve bunların kategorileri (düzeyleri) arasındaki çoklu uyumunun ölçmesi amaçlanmaktadır. Bunun için birinci aşamadaki duruma benzer bir mantık izlenir.

iki boyutlu uzayı açıklayan inertianın bu boyutlara paylaşımının yüksek oranda olacağı bir çözüm sunmak için yapılması gereken yollardan birisi olan değişkenler ve MCA ana boyutları arasındaki korelasyonu görselleştirerek karar vermek olduğuna göre; inovasyon etkinliği ve ilgili değişkenlerin temel boyutlar ile arasındaki korelasyonu Şekil 3'teki gibidir.

Şekil 3: Değişkenler ve Temel Boyutlar Arasındaki Korelasyon

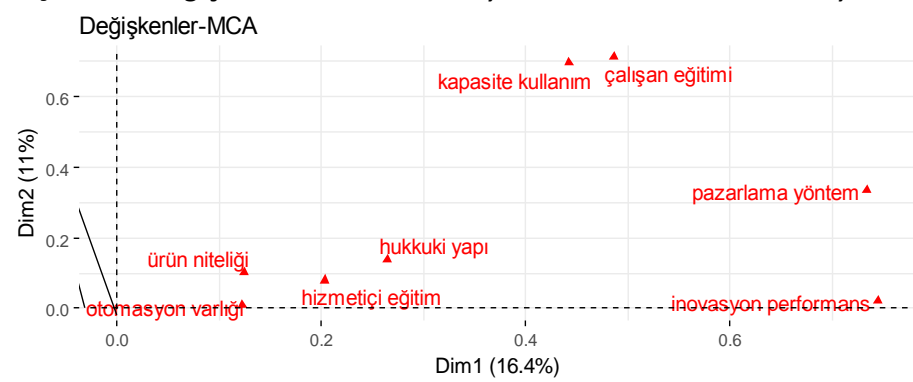

Değişkenler ve boyutlar arasındaki karesel korelasyonların koordinatlar olarak kullanıldığı Şekil 3, her bir boyutla en fazla ilişkili olan değişkenleri belirlemeye yardımcı olmaktadır. Buradan ihracat performansı ve pazarlama yöntemi değişkenlerinin 1. Boyutla ve çalışan eğitimi ve kapasite kullanımı değişkenlerinin hem 1. Boyutla hem de 2. Boyutla en çok ilişkili olduğu gözlemlenmektedir.

Inovasyon etkinliği ile anlamlı ilişki içerisinde olan değişkenler (faktörler) ve bunların kategorileri (düzeyleri) arasındaki uyumun daha belirgin ölçmesi (yani, ilk iki boyutun açıklama gücünün artırılabilmesi) için değişken azaltımına gidildiğine toplam değişim (inertia) içerisinde her bir boyuta düşen değişimin miktarları Tablo 8'de gösterilmektedir.

Tablo 9: Boyutların Toplam Değişimi Açıklama Oranları

\begin{tabular}{cccc}
\hline \multirow{2}{*}{ Boyutlar } & \multirow{2}{*}{ Varyans Inertia (Değişim) } & \multicolumn{2}{c}{ Boyutların toplam değişimi açıklama oranları } \\
\cline { 3 - 4 } & & \% Varyans (Açıklama payı) & Birikimli \% Varyans (Eklemeli pay) \\
\hline \hline 1 & 0,661 & 20,334 & 20,334 \\
2 & 0,477 & 14,669 & 35,003 \\
3 & 0,359 & 11,057 & 46,059 \\
4 & 0,349 & 10,733 & 56,793 \\
5 & 0,310 & 9,553 & 66,346 \\
6 & 0,252 & 7,768 & 74,114 \\
7 & 0,198 & 6,106 & 80,220 \\
8 & 0,171 & 5,271 & 85,491 \\
9 & 0,156 & 4,807 & 90,298 \\
10 & 0,120 & 3,698 & 93,996 \\
11 & 0,107 & 3,300 & 97,296 \\
12 & 0,059 & 1,812 & 99,108 \\
13 & 0,029 & 0,892 & 100,000 \\
\hline
\end{tabular}


Tablo 9'a göre en yüksek açıklama oranına sahip olan \%20,334'lik oranla birinci boyuttur (değişken azaltımı olmasaydı bu oran \%16,435 olacaktı). Açıklama oranları diğer boyutlarda adım adım düşmektedir. Toplam değişimi açıklamada ilk iki boyutun payının \%35,003 olduğu gözlemlenmektedir (değişken azaltması olmasaydı bu oran $\% 27,452$ olacaktı). Bir başka deyişle, bir uyum analizi çözümlemesi 13 boyutlu uzaydan 2 boyutlu uzaya indirgendiğinde toplam değişimin ancak \%35,003'lük kısmı açıklanmaktadır.

Boyutları açıklama ilişkisi düşük olan değişkenler atıldığında kalan değişkenler ile yapılan uyum analizinde ilk iki boyuttaki toplam değişimin açıklanan kısmı artmıştır. Böylece elde edilen değişken kategorileri arasındaki uyum Şekil 6'daki gibidir.

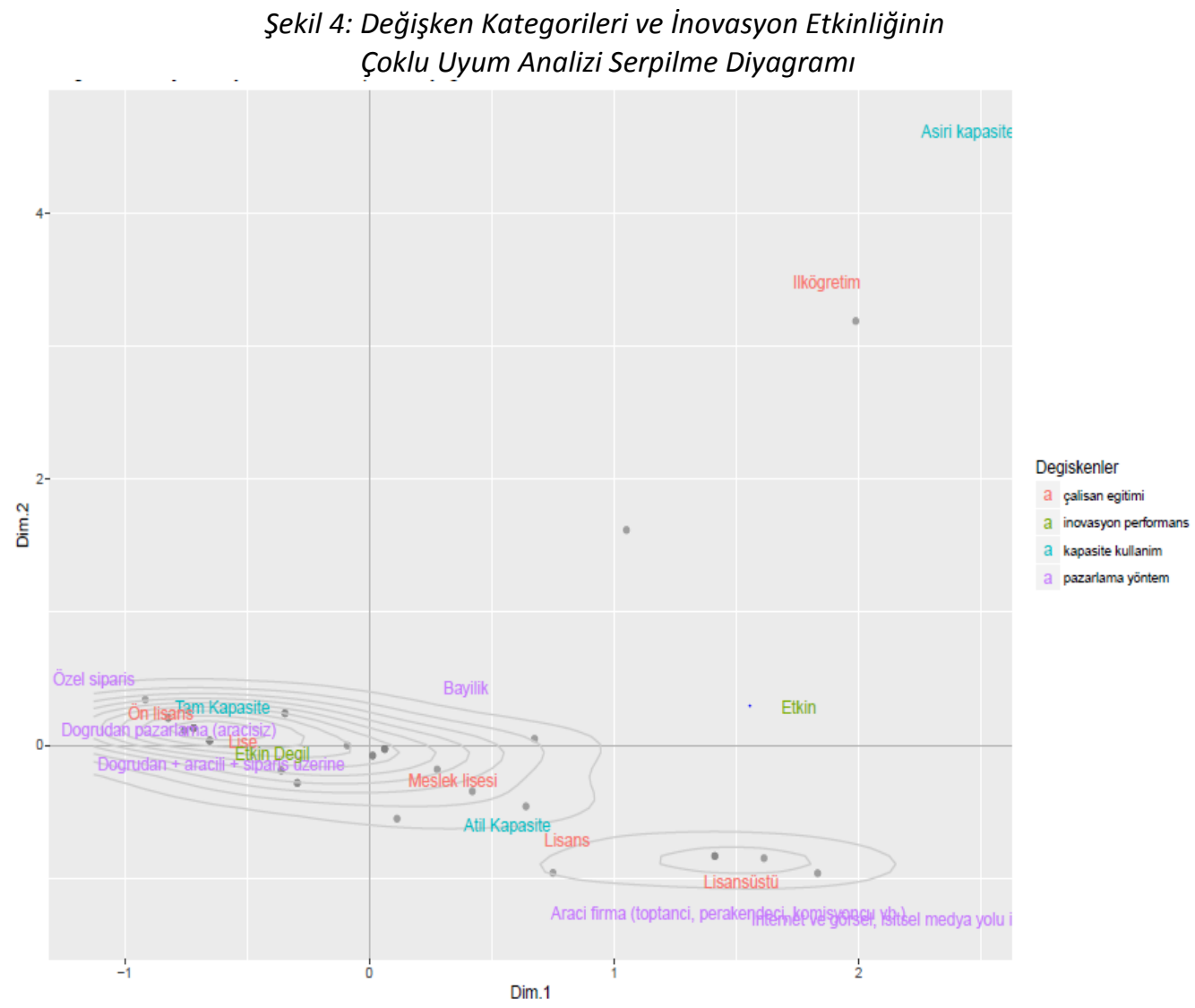

Elde edilen bulgulara göre; göreceli olarak inovasyon etkinliğini yakalayamayan firmaların pazarlama ve dağıtım yöntemlerinde yine internet görsel, işitsel medyayı kullanmadıkları, lisans seviyesinin altındaki düzeyde personel çalıştırdıkları ve atıl kapasite çalıştıkları gözlemlenmektedir. Göreceli olarak inovasyon etkinliğini yakalayan firmaların lisans ve üzeri kalifiye elaman çalıştırdıkları bununla birlikte internet görsel, işitsel medya ve aracı firmaları dağıtım kanalı olarak kullandıkları görülmektedir. 


\section{Sonuçlar}

Medikal sektörde faaliyet gösteren firmaların inovasyon ve ihracat etkinlikleri ile nitel karakteristikleri arasındaki ilişkinin varlığını ve uyumunu analiz etmek amacıyla hazırlanan çalışma üç aşamada ele alınmış ve şu sonuçlar elde edilmiştir.

Birinci aşamada, Veri Zarflama metodolojisinden yararlanılarak Samsun ilinde medikal sektöründe faaliyet gösteren firmaların hem ihracat hem de inovasyon performansları bakımından birbiri içerisinde göreceli olarak değerlendirilmesi yapılmıştır. Buna göre firmaların ihracat performansının ölçümü için çalışan sayısı, sahip olunan belge sayısı ve alınan ulusal/uluslararası hibe ve teşvik sayısı girdi değişkenleri, toplam satışlar içerisinde yıllık ortalama ihracat oranları çıktı değişkeni olarak belirlenmiştir. İnovatif performansının ölçümü için çalışan kalifiye eleman sayısı, firmaların sahip olduğu belge sayısı ve alınan ulusal ve uluslararası hibe ve teşvik sayısı girdi değişkeni firmaların marka, patent ve faydalı model varsallığı çıktı değiş̧keni olarak belirlenmiştir. Bunun için kaynak miktarının sabit tutulup çıktı miktarının mümkün olduğu kadar artırılması hedefi göz önüne alındığından çıktı odaklı DEA model yapısı ele alınmıştır.

38 firmanın değerlendirmeye alındığı modelde, sadece 3 Firma (Firma08, Firma12, Firma17) ihracat performansında diğerlerine göre tam etkin olduğu ve en verimli ölçek büyüklüğünde faaliyet gösterdiği sonucu çıkarılmaktadır. Ölçek etkinliğini sağlayan bu firmalar sabit ölçek özelliğine sahiptir. Geriye kalan diğer firmalar içerisinde 12 tanesi ihracatta etkin faaliyetler sergilediği ancak faaliyet gösterdiği dezavantajlı koşullardan (yönetim dışındaki coğrafi konum, iklim, vs. gibi dış etkilerden) dolayı potansiyellerini kullanamadıkları yani ölçek etkinliğini yakalayamadıkları sonucu çıkmaktadır.23 firmanın ise etkinsiz yönetimsel faaliyetlerinin hem de dezavantajı koşullarının mevcut olduğu gözlemlenmiştir. Ayrıca, 16 firma ölçeğe göre artan getiri özelliği sergilemektedir. Yani firmaların ihracat düzeylerinin oransal artışı girdi öğelerinin oransal artışından daha büyük olduğu sonucu çıkmaktadır. İşin ölçeği büyüyünce daha yoğun bir işbölümü ve uzmanlaşmanın oluşması bunun ortaya çıkma sebebidir. 19 firma ise ölçeğe göre azalan getiri sergilemektedir. Yani bu firmaların ihracat düzeylerinin oransal artışı girdi öğelerinin oransal artıştan daha küçüktür. Çalışma ölçeğindeki büyümeye bağlı olarak ortaya çıkacak iletişim bozuklukları sebebiyle işin etkin bir şekilde yürütmenin zorlaşması, bunun ortaya çıkma nedenidir.

Inovasyon performası bakımından ise sadece 12 firma diğerlerine göre tam etkin olduğu ve en verimli ölçek büyüklüğünde faaliyet gösterdiği gözlemlenmiştir. Ölçek etkinliğini sağlayan bu firmalar sabit ölçek özelliğine sahiptir. Geriye kalan diğer firmalar içerisinde 7 tanesi inovasyon performansında etkin faaliyetler sergilediği ancak faaliyet gösterdiği dezavantajlı koşullardan (yönetim dışındaki coğrafi konum, iklim, vs. gibi dış etkilerden) dolayı potansiyellerini kullanamadıkları yani ölçek etkinliğini yakalayamadıkları sonucu çıkmaktadır. 19 firmada ise hem etkinsiz yönetimsel faaliyetler hem de dezavantajlı koşullar mevcuttur. Ayrıca, inovasyonda ölçek etkinliğini yakalayamayan firmalar içerisinde 24 tanesi ölçeğe göre artan getiri özelliğini sergilemektedir. Yani firmaların inovasyon düzeylerinin oransal artışı girdi öğelerinin oransal artışından daha büyüktür. Bunun oluşma sebebi: işin ölçeği büyüdüğünde, daha yoğun bir işbölümü ve uzmanlaşmanın artmasıdır. 2 firma ise ölçeğe göre azalan getiri sergilemektedir. Yani bu firmaların inovasyon düzeylerinin oransal artışı girdi öğelerinin oransal artıştan daha küçüktür. Bunun ortaya çıkma nedeni: Çalışma ölçeğindeki büyümeye bağlı olarak ortaya çıkacak iletişim bozuklukları sebebiyle işi etkin bir biçimde yürütmenin adım adım zorlaşmasıdır. Buradan çoğu firmanın inovasyonda küçük üretim ölçeklerinde olduğu ortaya çıkmaktadır. Ortaya çıkan bir 
başka sonuç ise hem ihracatta hem de inovasyonda diğer firmalara göre göreceli olarak en iyi performansı sergileyen 1 tane firma (Firma17) olduğudur.

İkinci aşamada, firmaları global etkinlik skoruna göre "Etkin" ve "Etkinsiz" biçiminde iki gruba ayrılarak nitel ölçek haline getirilen performans değişkenleri ile nitel karakterli firma özelliklerini yansıtan değişken grubu arasında ilişki bulunup bulunmadığını incelemek için ki-kare bağımsızlık testinden faydalanıımıştır. Üretilen/satılan ürün niteliği, otomasyon (bilişim) sisteminin varlığı, kapasite kullanım oranları ve çalışanların genel eğitim durumları ile inovasyon etkinliği arasında anlamlı bir bağımlılığın bir ilişkinin olduğu sonucu çıkarılmıştır. Ihracat etkinliği ile farklı kuruluşlardan alınan hibe teşvik desteği arasında anlamlı bir ilişki olduğu sonucu da ortaya çıkmaktadır. KOSGEB ve Diğer kuruluşlardan hibe teşvik alınıp alınmaması durumunun ihracat etkinliği ile anlamlı bir ilişki içerisinde oldukları gözlemlenmiştir.

Üçüncü aşamada ise ihracat ve inovasyon etkinliği ile anlamlı ilişki içerisinde olan değişkenler (faktörler) ve bunların kategorileri (düzeyleri) arasındaki çoklu uyumunun ölçmesi sağlanmıştır. Buna göre göreceli olarak ihracat etkinliğini yakalayamayan firmaların pazarlama ve dağıtım yöntemlerinde internet görsel, işitsel medya'yı kullanmadıkları, herhangi bir kuruluştan hibe teşvik desteği almadıkları, limited ve anonim ortaklıklar olduğu gözlemlenmiştir. Göreceli olarak inovasyon etkinliğini yakalayamayan firmaların ise pazarlama ve dağıtım yöntemlerinde yine internet görsel, işitsel medya'yı kullanmadıkları, lisans seviyesinin altındaki düzeyde personel çalıştırdıkları ve atıl kapasite çalıştıkları, buna karşın göreceli olarak inovasyon etkinliğini yakalayan firmaların ise lisans ve üzeri kalifiye elaman çalıştırdıkları bununla birlikte internet görsel, işitsel medya ve aracı firmaları dağıtım kanalı olarak kullandıkları gözlemlenmiştir. 


\section{Kaynaklar}

Akal, Zühal (2005), İşletmelerde Performans Ölçüm ve Denetimi Çok Yönlü Performans Göstergeleri, Ankara: Milli Prodüktivite Merkezi Yayınları

Banker, Rajiv D; Charnes, Abraham; Cooper, William W (1984), "Some Models for Estimating Technical and Scale Inefficiencies in Data Envelopment Analysis", Management Science, Vol. 30, No. 9: 1078-1092.

Baspinar, Ebru; Mendes, Mehmet (2000), "iki Yönlü Tablolarda Uyum Analizi Tekniğinin Kullanımı", AUZF Tarım Bilimleri Dergisi, C. 6, S. 2: 98-106.

Charnes, Abraham; Cooper, William W; Rhodes, Edwardo (1978), "Measuring the efficiency of decision making units", European journal of operational research, Vol. 2, No. 6: 429-444.

Coelli, Tim; Perelman, Sergio (2000), "Technical efficiency of European railways: a distance function approach", Applied Economics, Vol. 32, No. 15: 1967-1976.

Cooper, William W., Seiford, Lawrence M., Zhu, Joe (2011), Data envelopment analysis: History, models, and interpretations, In Handbook on data envelopment analysis, Boston: Springer, MA.

Devillers, James; Karcher, Walter (2013), Applied multivariate analysis in SAR and environmental studies, Euro Courses, Chemical and Environmental Science, (Vol. 2): Springer Science \& Business Media.

"The European medical technology industry in figures, Brussels: MedTech Europe", https://www.medtecheurope.org/wp-content/uploads/2018/06/MedTech-Europe_FactsFigures2018_FlNAL_1.pdf (Erişim: 10.01.2018).

Førsund, Finn R; Sarafoglou, Nikias (2002), "On the origins of data envelopment analysis", Journal of Productivity Analysis, Vol. 17, No. 1-2: 23-40.

Gifi, Albert (1990), Nonlinear multivariate analysis, Chichester: Wiley

Greenacre, Michael; Blasius, Jorg (2006), Multiple correspondence analysis and related methods, CRC press: Chapman and Hall/CRC.

Greenacre, Michael; Hastie, Trevor (1987), "The geometric interpretation of correspondence analysis", Journal of the American statistical association, Vol. 82, No. 398: 437-447.

Kaynak, Selahattin (2016), "Türk İlaç Sektörünün Rekabet Yapısı ve Yoğunlaşma Analizi", Çankırı Karatekin Üniversitesi iiBF Dergisi, C. 6, S. 2: 49-66.

Kaynak, Selahattin; Altuntas, Serkan; Dereli, Türkay (2017), "Comparing the innovation performance of EU candidate countries: an entropy-based TOPSIS approach", Economic research-Ekonomska istraživanja, Vol. 30, No. 1: 31-54.

Kiper, Mahmut (2013), Dünyada Ve Türkiye 'de Tıbbi Cihaz Sektörü Ve Strateji Önerisi, Ankara: Türkiye Teknoloji Geliştirme Vakfı.

Kutlar, Aziz; Babacan, Adem (2008), "Türkiye'deki Kamu Üniversitelerinde CCR Etkinliği-Ölçek Etkinliği Analizi: DEA Tekniği Uygulaması", Kocaeli Üniversitesi Sosyal Bilimler Enstitüsü Dergisi, C. 15, S. 1:, 148-172.

Mendeş, Mehmet (2002), "Çoklu uyum analizi tekniğinin kullanımı", Ziraat Mühendisliği Dergisi, C. 10, S. 2: 337, 32-35.

Arık, Özer; İleri, Yusuf Yalçın; Buğra, Kaya (2016), "Sağlık Hizmetlerinde Tıbbi Cihaz Sektörü", Hacettepe Sağlık idaresi Dergisi, C. 19, S. 2: 187-202.

Sağlık Bakanlığı (2017), Türkiye tıbbi cihaz sektörü strateji belgesi ve eylem planı (2017-2021), http://www.egemedikalder.org/wp-content/uploads/2017/04/T\%C4\%B1bbi-Cihaz-Sekt\%C3\%B6r-Stratejisi-Belgesi-ve-EylemPlan\%C4\%B1-2017-2021-05-04-2017.pdf (Erişim: 01.12.2018).

Williams, Lynne J; Abdi, Hervé; French, Rebecca; Orange, Joseph B (2010), "A tutorial on multiblock discriminant correspondence analysis (MUDICA): a new method for analyzing discourse data from clinical populations", Journal of Speech, Language, and Hearing Research, Vol. 53, No. 5: 1372-1393.

Yaylalı, Muammer; Kaynak, Selahattin; Karaca, Zeynep (2012), "Sağlık Hizmetleri Talebi: Erzurum Ilinde Bir Araştırma", Ege Akademik Bakış, C. 12, S. 4: 563-573.

Yükçü, Süleyman; Atağan, Gülşah (2009), "Etkinlik, Etkililik ve Verimlilik Kavramlarının Yarattığı Karışıklık", Atatürk Üniversitesi Iktisadi ve Idari Bilimler Dergisi, C. 23, S. 4: 1-13. 
Eskişehir Osmangazi Üniversitesi IißBF Dergisi 